\title{
Dynamics of proinflammatory cytokines at phlegmons of the maxillofacial area
}

\author{
U.D. Matolych, O.Z. Masna-Chala, L.Y. Lapovets, B.V. Dzhuran \\ Danylo Halytsky Lviv National Medical University,Ukraine; e-mail: ulyanam23@gmail.com
}

\begin{abstract}
Despite the continuous improvement of diagnosis and treatment, phlegmons of the maxillofacial area is one of the first places in the clinic of maxillofacial surgery. The concentrations of proinflammatory cytokines 6 , 8,17 were estimated in the serum of patients with this pathology with different spread of inflammation in the dynamics of treatment. It is shown that the level of cytokines in the patients under research was higher than in the control group. It is established that maintaining high concentrations of interleukin-6 (IL-6, 14.6-34.8 ng/l), IL-8 (17.3-26.8 ng/l), IL-17 (17.0-20.9 ng/l) during the treatment period (9 days) leads to complications, progression of inflammatory processes. Thus, excessive production of cytokines leads to the appearance of severe pathological conditions in a human body. During the treatment, a strong direct correlation between IL-6 and IL-17, and IL-8 and IL-17 was established which may indicate a combined synergistic effect of the studied cytokines. Evaluation of the level of the cytokines during the disease can be important for determining treatment strategy of patients with phlegmons of the maxillofacial area. Key words: phlegmons of the maxillofacial area; interleukin-6; interleukin-8; interleukin-17.
\end{abstract}

\section{INTRODUCTION}

Pyoinflammatory pathological states have been the topical issue in the maxillofacial surgery. Thus, according to the latest data odontogenic phlegmons cause $30-40 \%$ of all maxillofacial diseases allowing to regard this pathology not only as a medical problem but also as an important social issue [1-3]. In $65 \%$ of all cases the clinical pattern phlegmons of the maxillofacial area is inconsistent with the topical diagnostics and the relevant local manifestations making it difficult to provide early and precise diagnostics as well as the required care delivery [4]. The quantity of patients with the vague clinical pattern and inert course of disease have been increasing making the diagnostics of inflammatory complications coursed by phlegmons (mediastinitis, intracerebral complications, sepsis, facial vein and cavernous sinus thrombosis) more challenging $[5,6]$.

Cytokines (interleukins - IL) serving as the immune system mediators perform the universal regulatory function [7-9]. IL-7 was proved to regulate and activate the synthesis of IL- 6 and IL- $8[10,11]$. The activation of macrophage and neutrophil chemokinesis in the inflammation focus area is the key immunobiological role of IL-17. IL-17 is generated by T-helpers [12-14]. IL-6 links cells in the inflammation focus and other tissues to achieve the most adequate response and agent's elimination. IL-6 is the main finishing stage inducer of the macrophage and B-lymphocyte differentiation [15, 16]. IL-8 is one of the early inflammation mediators referring to the chemokine group. It plays a significant role in causing and maintaining inflammation, in the migration of neutrophils into the inflammation focus and in the activation of the adhesion molecule synthesis. The activated macrophages, monocytes and endothelial cells are main IL-8 producing cells $[17,18]$.

In the up-to-date clinical practice the treatment result depends on the early and relevant diagnostics, therapeutic approaches with due account for the special aspects of the wound process course. The investigation of cytokine 
immune regulation mechanisms revealed in the course phlegmons of maxillofacial area is a topical medical issue.

The aim of the research is to investigate the dynamics of the amount of IL-17, IL-6, IL-8 in the blood serum of patients with phlegmons of the maxillofacial area.

\section{METHODS}

35 apparently healthy people (the observational group) were examined, 34 of which were suffering from phlegmons localized in one anatomical area (the $1^{\text {st }}$ group), phlegmons located in two anatomical groups (the $2^{\text {nd }}$ group) were revealed in 35 patients; the localization of phegmons in three or more anatomical areas was observed in 20 patients (the $3^{\text {rd }}$ group). Diagnosis was determined according to the patients complaints, disease and life history, objective and local status, clinical and laboratory tests. The patients underwent surgical intervention, the suppurative focuses were prosected, postsurgical wounds were drained and the "causative teeth" were removed.

The level of IL-6, IL- 8 and IL-17 in the blood serum was defined by applying enzyme multiplied immunoassay using the set of chemical agents and following the instructions set by the "Diaclone" producer (France). Examination was conducted three times: before treatment (the $1^{\text {st }}$ day), on the $5^{\text {th }}$ and $9^{\text {th }}$ days following the surgery.

The correct allocation received in the primary results was reviewed by applying Shapiro Wilk test having shown the evidence of the Gaussian allocation type. The research results are shown as arithmetic average values and standard deviations $(\mathrm{M} \pm \mathrm{m})$. t Student criterion along with Bonferroni's adjustment were applied for estimating possible differences between the two groups. The correlation relations between the received indexes were studied by applying Pearson's code. Main calculations were made in Excel 2013.

\section{RESULTS AND DISCUSSION}

The level of IL-6, IL-8 and IL-17 revealed in the observational group and in patients is shown in Table 1-3. The level of cytokines observed in the blood serum of patients under study was higher than that in the observational group.

The possible changes of IL-6 level as compared to the control carried out on the $1^{\text {st }}$ and $9^{\text {th }}$ day were not revealed in the $1^{\text {st }}$ group. The IL-6 level in the $2^{\text {nd }}$ group was exceeding the control rate and the $1^{\text {st }}$ group indexes $(\mathrm{P}<0.05)$ during 9 days but was apparently the same on the $1^{\text {st }}$, $5^{\text {th }}$ and $9^{\text {th }}$ days. This index was 5 times higher on the $1^{\text {st }}$ day in the $3^{\text {rd }}$ group as compared to the $1^{\text {st }}$ group, 1.6 times higher than in the $2^{\text {nd }}$ group and 3.8 times higher than in the observational group $(\mathrm{P}<0.05)$. The 1.5 decrease of cytokine level $(\mathrm{P}<0.05)$ in comparison with the previous value was observed being apparently caused by the process chronization: the period with no clinical manifestations and the residual purulence revealed after suppurative focuses have been prosected and drained. The increase of IL- 6 level in 2.4 times was observed on the $9^{\text {th }}$ day. IL-6 penetrates into the system circulation causing distant affects. The decrease of IL-6 followed by its sharp rise without any satisfactory dynamics is a predictably unfavourable factor that shall be taken into consideration while giving the integrated evaluation of indications for planning the treatment of a suppurative wound. The increase of IL- 6 generation gives evidence of the protective mechanism required for the initial inflammation stage. Nevertheless, in cases when an inadequate increase of the activation degree is revealed the protective mechanism turns into a pathological one.

IL-6 activates the surrounding tissues and IL-8 is a chemokine for hemophage causing inflammation. The highest IL-8 level (13 times exceeding the control rate) was revealed in the $3^{\text {rd }}$ group on the $1^{\text {st }}$ day $(\mathrm{P}<0.05)$ complying with the maximum activation of immune cells in the inflammation focus and allowed to predict a more severe course of disease. A tendency of IL- 8 decreasing up to the 
Table 1. The level of IL-6 in blood serum of patients with phlegmons of the maxillofacial area (ng/l)

\begin{tabular}{|c|c|c|c|}
\hline \multirow{2}{*}{ Test pattern, Research groups } & \multicolumn{3}{|c|}{ Research terms } \\
\hline & the $1^{\text {st }}$ day & the $5^{\text {th }}$ day & the $9^{\text {th }}$ day \\
\hline Control rate & $5.8 \pm 0.4$ & $5.8 \pm 0.4$ & $5.8 \pm 0.4$ \\
\hline Phlegmongs & & & \\
\hline in one area (the $1^{\text {st }}$ group) & $4.3 \pm 0.3$ & $7.3 \pm 0.2 *$ & $6.2 \pm 0.3$ \\
\hline in two areas (the $2^{\text {nd }}$ group) & $13.6 \pm 0.2 * * *$ & $12.4 \pm 0.3 * * *$ & $11.4 \pm 0.5 * * *$ \\
\hline in three and more areas (the $3^{\text {rd }}$ group) & $22.3 \pm 0.3 *, * *, * * *$ & $14.6 \pm 0.7 * * *$ & $34.8 \pm 0.3 *, * *, * * *$ \\
\hline
\end{tabular}

Note. Here and in Tables 2, 3:* $\mathrm{P}<0.05$ as compared to the control rate; ${ }^{* *} \mathrm{P}<0.05$ as compared to the $1^{\text {st }}$ group; *** $\mathrm{P}<0.05$ as compared to the $2^{\text {nd }}$ group.

$9^{\text {th }}$ day was observed in the course of treatment, though the index was 7 and 8.6 times apparently exceeding the control rate in the $2^{\text {nd }}$ and $3^{\text {rd }}$ groups correspondingly. The increase of cytokine level in the examined groups complied with the severity of phlegmons manifestations. Correspondingly, the increased IL-8 level in blood serum intensifies the local inflammation process.

One should note that the possible increase of IL-17 level in patients suffering from phlegmons of the maxillofacial area is the evidence of severe inflammation. A positive dynamics was observed in the $1^{\text {st }}$ group: the level of IL-17 decreased 1.8 times on the $9^{\text {th }}$ day in comparison with the $1^{\text {st }}$ day and was approaching the normal physiological rates. The apparent decrease of IL-17 level was revealed in the $2^{\text {nd }}$ group being 3 times higher than in the observational group on the $9^{\text {th }}$ day. The received result proves the evidence of a highly activated inflammation process. On the $5^{\text {th }}$ day cytokine under study decreased in the $3^{\text {rd }}$ group as compared to the initial value at that exceeding the relevant indexes of healthy people $(\mathrm{P}<0.05)$. The level of IL-17 on the $9^{\text {th }}$ day increased as compared to the $5^{\text {th }}$ day $(\mathrm{P}<0.05)$ : apparently exceeding the control rate, the $1^{\text {st }}$ and the $2^{\text {nd }}$ groups in $8.5,5.7$ and 2.7 times correspondingly. Thus, the high level of IL-17 shows the disease severity, ineffective treatment and the risk of possible complications.

The levels of IL-6, IL-8 and IL-17 decrease in parallel with the regression of clinical symptoms though being still increased and, thus, indicating inflammation.

Comparing the outcomes of the groups under study one should note that the excessive production of cytokines on the $9^{\text {th }}$ day gives evidence to the inflammation generalization and to the turning of a local process into a systemic one requiring treatment correction.

Pair correlation coefficients between proinflammation cytokines in patients with phlegmons of the maxillofacial area were defined.

In case of no pathology and under normal conditions subtle correlation relations are observed in immune system allowing for a reasonable correction of slight homeostasis deviations inducing no stress in the system. In cases phlegmons of the maxillofacial area and with evident pathological findings the density and quantity

Table 2. The level of IL-8 in blood serum of patients with phlegmons of the maxillofacial area (ng/l)

\begin{tabular}{|c|c|c|c|}
\hline \multirow{2}{*}{ Test pattern, Research groups } & \multicolumn{3}{|c|}{ Research terms } \\
\hline & the $1^{\text {st }}$ day & the $5^{\text {th }}$ day & the $9^{\text {th }}$ day \\
\hline Control rate & $2.0 \pm 0.2$ & $2.0 \pm 0.2$ & $2.0 \pm 0.2$ \\
\hline Phlegmons & & & \\
\hline in one area (the $1^{\text {st }}$ group) & $6.3 \pm 0.2 *$ & $5.2 \pm 0.6^{*}$ & $3.5 \pm 0.4$ \\
\hline in two areas (the $2^{\text {nd }}$ group) & $19.6 \pm 0.2 * * *$ & $17.6 \pm 0.4 * * *$ & $14.4 \pm 0.3 * * *$ \\
\hline in three and more areas (the $3^{\text {rd }}$ group) & $26.8 \pm 0.5 *, * *, * * *$ & $21.4 \pm 0.3 * * *$ & $17.3 \pm 0.2 * * *$ \\
\hline
\end{tabular}


Table 3. The level of IL-17 in the blood serum of patients with phlegmons of the maxillofacial area (ng/l)

\begin{tabular}{|c|c|c|c|}
\hline \multirow{2}{*}{ Test pattern, Research groups } & \multicolumn{3}{|c|}{ Research terms } \\
\hline & the $1^{\text {st }}$ day & the $5^{\text {th }}$ day & the $9^{\text {th }}$ day \\
\hline Control rate & $2.2 \pm 0.8$ & $2.2 \pm 0.8$ & $2.2 \pm 0.8$ \\
\hline Phlegmons & & & \\
\hline in one area $(\mathrm{t}$ & $5.5 \pm 0.4 *$ & $4.7 \pm 0.3 *$ & $3.3 \pm 0.1$ \\
\hline in two areas (the $2^{\text {nd }}$ group) & $13.5 \pm 0.7 * * *$ & $9.5 \pm 0.4 * * *$ & $7.0 \pm 0.4 * * *$ \\
\hline in three and more areas (the $3^{\text {rd }}$ group) & $20.9 \pm 0.4 * * *$ & $17.0 \pm 0.4 *, * *, * * *$ & $18.9 \pm 0.9 *, * * * * *$ \\
\hline
\end{tabular}

of correlation relations is increased. Thus, the change of one index results in the change of other immune system indexes being not always reasonable. The comparative analysis of correlation links between the levels of IL-6, IL-8 and IL-17 in blood serum the phlegmons localized in three and more anatomical areas show strong positive correlative relations: IL- 6 vs IL- 8 $(\mathrm{r}=+0.69, \mathrm{r}=+0.62, \mathrm{P}<0.05)$ on the $1^{\text {st }}$ and $5^{\text {th }}$ days correspondingly, IL-6 vs IL-17 $(\mathrm{r}=+0.87$, $\mathrm{P}<0.05)$ and IL- 8 vs IL-17 $(\mathrm{r}=+0.83, \mathrm{P}<0.05)$ on the $9^{\text {th }}$ day. It reflects the involvement of cytokines in the activation of the inflammation response: the progress of this pathological find-

Table 4. Correlation coefficients of the interleukins in cases with phlegmons of maxillofacial area

\begin{tabular}{|c|c|c|c|}
\hline \multirow{2}{*}{$\begin{array}{l}\text { Research terms, different } \\
\text { types of interleukin combi- } \\
\text { nation }\end{array}$} & \multicolumn{3}{|c|}{ Research groups } \\
\hline & $\begin{array}{l}\text { Phlegmons in one area } \\
\text { (the } 1^{\text {st }} \text { group) }\end{array}$ & $\begin{array}{l}\text { Phlegmons in two areas } \\
\text { (the } 2^{\text {nd }} \text { group) }\end{array}$ & $\begin{array}{l}\text { Phlegmons in three and } \\
\text { more groups (the } 3^{\text {rd }} \text { group) }\end{array}$ \\
\hline \multicolumn{4}{|l|}{ The $1^{\text {st }}$ day } \\
\hline IL 6 vs IL 8 & $0.37 *$ & $-0.66^{*}$ & $0.69 *$ \\
\hline IL 6 vs IL 17 & $0.36^{*}$ & $0.47 *$ & $0.45 *$ \\
\hline IL 8 vs IL 17 & 0.16 & $0.51 *$ & $0.43^{*}$ \\
\hline \multicolumn{4}{|l|}{ The $5^{\text {th }}$ day } \\
\hline IL 6 vs IL 8 & $0.45 *$ & $0.47 *$ & $0.62 *$ \\
\hline IL 6 vs IL 17 & 0.20 & $0.55^{*}$ & $0.50 *$ \\
\hline IL 8 vs IL 17 & $0.36^{*}$ & $0.56^{*}$ & $0.55 *$ \\
\hline \multicolumn{4}{|l|}{ The $9^{\text {th }}$ day } \\
\hline IL 6 vs IL 8 & $0.33^{*}$ & $0.39 *$ & $-0.76^{*}$ \\
\hline IL 6 vs IL 17 & 0.12 & $0.53 *$ & $0.87 *$ \\
\hline IL 8 vs IL 17 & 0.18 & $0.42 *$ & $0.83 *$ \\
\hline
\end{tabular}

* apparent correlation coefficients

ing is caused by the activation of IL-6, IL-8, IL-17 generation.

The establishing of critical levels of cytokines involved in phlegmons of the maxillofacial area immunogenesis (IL-6 (14.6-34.8 ng/1), IL-8 (17.3-26.8 ng/1), IL-17 (17.0-20.9 $\mathrm{ng} / \mathrm{l})$ ) is important information pointing at the necessity of the relevant care delivery aimed at the prevention of possible complications and vocational rehabilitation.

\section{CONCLUSIONS}

1. The identified indexes of IL-6, IL-8, IL-17 level in blood serum prove that the cytokine regulation of the immune response in cases in phlegmons of the maxillofacial area is necessary for the development of adequate protective body reactions for the insertion of a pathogenic agent while the regulation disruption causes the progress of a pathological process.

2. The high level of IL-6 (14.6-34.8 ng/1), 
IL-8 (17.3-26.8 ng/1), IL-17 (17.0-20.9 ng/1) during the treatment period (observation was made for 9 days) indicates the increased risk of complications and the pyoinflammatory progression.

3 . The received data shows the possible relations between the levels of IL-6, IL-8, IL-17 in blood serum and the course of disease: severe clinical manifestations are associated with a high level of cytokines. The revealed correlation links between the cytokines under study prove the important role played by IL-6, IL-8, IL-17 in the phlegmons of the maxillofacial area pathogenesis and the development of complications. Strong direct correlation relations between IL-6, IL-8, IL-17 are the most evident.

4. As far as the levels of IL-6, IL-8, IL17 in blood serum of patients suffering from phlegmons of the maxillofacial reflect the degree of inflammation activation and serve as an important immunological factor, the research of cytokine in their dynamics is a promising trend for defining treatment strategy and for applying an individual approach towards every patient.

5 . The apparent parallelism of decreasing IL6, IL-8, IL-17 levels can indicate the combined synergetic effect of the studied cytokines.

\section{У.Д. Матолич, О.З. Масна-Чала, Л.Є. Лаповець, Б.В. Джуран \\ ДИНАМІКА ПРОЗАПАЛЬНИХ ЦИТОКІНІВ ПРИ ФЛЕГМОНАХ ЩЕЛЕПНО-ЛИЦЕВОЇ ДІЛЯнкИ}

Флегмони щелепно-лицевої ділянки, незважаючи на вдосконалення лікування і діагностики, посідають одне 3 перших місць у клініці щелепно-лицевої хірургії. Досліджено вміст прозапальних цитокінів $6,8,17$ у сироватці крові хворих $з$ флегмонами щелепно-лицевої ділянки в динаміці лікування. Показано, що вміст цитокінів у цих пацієнтів був вищим, ніж у контрольній групі. Встановлено, що збереження високого вмісту інтерлейкіну-6 (IL-6, 14,6-34,8 нг/л), IL-8 (17,3-26,8 нг/л), IL-17 (17,0-20,9 нг/л) протягом періоду лікування (9 діб) призводить до розвитку ускладнень, прогресування гнійно-запального процесу. Отже, надмірна продукція цитокінів призводить до розвитку важких патологічних станів у організмі. У динаміці лікування встановлені сильні прямі кореляційні зв'язки між IL-6 та IL-17, IL-8 та IL-17, що можуть вказувати на поєднаний синергійний вплив досліджуваних цитокінів. Оцінка вмісту цих цитокінів у динаміці захворювання може бути важливою для своєчасного виявлення ускладнень, визначення стратегії лікування хворих на флегмони щелепно-лицевої ділянки.

Ключові слова: флегмони щелепно-лицевої ділянки; інтерлейкін-6; інтерлейкін-8; інтерлейкін-17.

\section{У.Д. Матолич, О.3. Масна-Чала, Л.Е. Лаповец,} Б.В. Джуран

\section{ДИНАМИКА ПРОВОСПАЛИТЕЛЬНЫХ ЦИ- ТОКИНОВ ПРИ ФЛЕГМОНАХ ЧЕЛЮСТНО- ЛИЦЕВОЙ ОБЛАСТИ}

Флегмоны челюстно-лицевой области, несмотря на совершенствование лечения и диагностики, занимают одно из первых мест в клинике челюстно-лицевой хирургии. Исследованы содержание провоспалительных цитокинов 6, 8, 17 в сыворотке крови больных с флегмонами челюстно-лицевой области в динамике лечения. Показано, что содержание цитокинов у этих пациентов был выше, чем в контрольной группе. Установлено, что сохранение высокого содержания интерлейкина-6 (IL-6, 14,6-34,8 нг/л), IL-8 (17,3-26,8 нг/л), IL-17 (17,0-20,9 нг/л) в течении периода лечения (9 суток) приводит к развитию осложнений, прогрессированию гнойно-воспалительного процесса. Итак, избыточная продукция цитокинов приводит к развитию тяжелых патологических состояний в организме. В динамике лечения установлены сильные прямые корреляционные связи между IL-6 и IL-17, IL-8 и IL-17, которые могут указывать на совмещенное синергетическое воздействие исследуемых цитокинов. Оценка содержания этих цитокинов в динамике заболевания может быть важной для своевременного выявления осложнений, определение стратегии лечения больных с флегмонами челюстно-лицевой области.

Ключевые слова: флегмоны челюстно-лицевой области; интерлейкин-6; интерлейкин-8; интерлейкин-17.

\section{REFERENCES}

1. Kabanova AA, Pohodenko-Chudakova IO. Inflammatory processes of maxillofacial area and neck. Modern approach to the diagnosis, prognosis and treatment. Mil Med. 2013; 3: 125-9.

2. Flynn TR. Anatomy and surgical therapy of oral and maxillofacial infections. J Oral Maxillofac Surg. 2004; 62: 86-7.

3. Matolych UD, Lapovets LE, Horhota AI. Dynamics of cellular immunity in patients with maxillofacial phlegmons. Lab Diagn East Eur. 2015; 1(13): 103-9.

4. Morozova MN, Krasnikov VO, Viborniy VG. Evaluation of the seventy of patients condition in cases of odontogenous phlegmons of the maxillofacial area and making the prognosis for their treatment. Vis Stom. 2009; 2: 64-9. [Ukrainian]. 
5. Durnovo EA, Vysel'tseva YuV, Mishina NV, Khomutinnikova NE, Marochkina MS. Peculiarities of clinicoimmunological diagnostics of common inflammatory disease of the soft tissues in the maxillofacial region and their complications. Russ J Dentist. 2012; 3: 22-6.

6. Matolych UD, Kaminsky VI, Kaminsky VV. The analysis of inflammatory diseases of the soft tissues of the maxillofacial area. Coll Scient Pap Inst Dent Shupyk Nat Med Acad Postgrad Educ. 2014; 5: 7-9. [Ukrainian].

7. Serebrennikova S, Seminsky I. The role of cytokines in the inflammatory process. Siber Med J. 2008; 8: 5-8.

8. Akhmedov GD. Evaluation of the cytokine status in patients with infectious and inflammatory complications of surgical interventions in the oral cavity. Dental Inst. 2012; 1(54): 82-3.

9. Nikitin YeV, Chaban TV, Servetsky SK. Modern notions about system of cytokines. Infect Dis. 2013; 2: 64-9. [Ukrainian]

10. Kologrivova IV, Kologrivova YeN, Suslova TYe. Molecular aspects of the T-helpers type 17 functioning. Bull Sib
Med. 2011; 4: 93-8.

11. Hirata T, Osuga Y, Hamasaki K. Interleukin (IL)-17A Stimulates IL-8 Secretion, Cyclooxygenase-2 Expression, and Cell-Proliferation of Endometriotic Stromal Cells. Endocrinology. 2008; 149(3): 1260-7.

12. Ketlinsky SA. Th 17 - a new line of differentiation of T helper cells: a review of the data. Cytokines Inflamm. 2009; 8(2): 24-39.

13. Chang SH, Dong C. A novel heterodimeric cytokine consisting of IL-17 and IL-17F regulates inflammatory responses. Cell Res. 2007; 17(5): 435-40.

14. Jin W, Dong C. IL-17 cytokines in immunity and inflammation. EMI. 2013; 2(9): 52-60.

15. Scheller J, Chalaris A, Schmidt-Arras D, Rose-John S. The proinflammatory properties of the cytokine interleukin-6. BBA-Molecul Cell Res. 2011; 1813(5): 878-88.

16. Yamamoto K, Rose-John S. The biology of interleukin-6. Clin Pharmacol Ther. 2012; 91: 574-6.

17. Allen T, Kurdowska A. Interleukin 8 and Acute Lung Injury. Lab Med. 2014; 138(2): 266-9. 